\title{
Rastreamento e certificação de resíduos lenhosos gerados nas cidades
}

\author{
Rodolpho Schmidt
}

Grupo Cia Brasileira de Florestas Tropicais

Engenheiro Florestal, rodolpho@cbft.com.br

\section{RESUMO}

Ferramentas digitais para manejo florestal urbano. Plataforma Madeira Urbana $\mathbb{B}$, organização com rastreamento e certificação de resíduos lenhosos urbanos. A importância do rastreamento e certificação para empresas de Gestão de Resíduos, Serrarias e Marcenarias. Experiências com uso da madeira certificada Madeira Urbana.

Palavras-chave: plataforma digital, rastreamento, certificação, madeira urbana.

\begin{abstract}
Digital tools for urban forest management. Madeira Urbana B Platform, organization with tracking and certification of urban wood waste. The importance of tracking and certification for Waste Management, Sawmills and Joinery companies. Experiences with the use of certified wood Madeira Urbana.
\end{abstract}

Keywords: digital platform, tracking, certification, urban wood. 